\title{
Fuel value indices of selected woodfuel species used in Masindi and Nebbi districts of Uganda
}

\author{
Samuel Ojelel ${ }^{1 *}$, Tom Otiti ${ }^{2}$ and Samuel Mugisha ${ }^{1}$
}

\begin{abstract}
Background: Biomass currently meets more than $97 \%$ of the total energy requirements in Uganda. However, contrary to this heavy reliance on biomass, there is paucity of information regarding the fuel value indices (FVIs) of woodfuel species used in different locations of the country such as Masindi and Nebbi districts. This study therefore sought to identify ten woodfuel species commonly used by the communities in these two districts and examine their FVIs from basic properties, namely; moisture content, density and gross calorific value.
\end{abstract}

Methods: A semi-structured interview using a checklist of guiding questionnaire was conducted to generate a woodfuel species list. The familiarity index (FI) was calculated for each species and then used to rank ten commonly used species for further analysis. The moisture content, density and gross calorific value of the selected species were determined in triplicate. The FVI of each species was then determined from these basic properties. One-way ANOVA, Pearson product moment correlation, and Spearman rank correlation coefficient analyses were performed in SPSS ver.16.0 to examine the variation and relationship of variables.

Results: Ten woodfuel species belonging to seven families and eight genera were identified as commonly used species. Combretum collinum was mentioned by every respondent as a suitable woodfuel species. A significant variation in moisture content and density was recorded among the species $(F(d f=9)=92.927, p=0.0001)$ unlike in gross calorific value $\left.\left(F_{(} d f=9\right)=1.400, p=0.253\right)$. There was a positive correlation between density and gross calorific value $(r=0.895, n=30, p=0.0001)$ and a negative correlation between moisture content and gross calorific value ( $r=-0.518, n=30, p=0.003$ ). The FVls obtained ranged from 1.10 in Ficus natalensis to 13.09 in Albizia grandibracteata. There was also a positive relationship $(r h o=0.62)$ between FVIs and Fls using Pearson rank correlation coefficient.

Conclusions: Moisture content and density are important properties in the selection of woodfuel species than gross calorific value. On the proposition of the FVIs, A. grandibracteata is a suitable woodfuel species than F. natalensis. These findings fit well into the ongoing efforts by Government and Civil Society Organizations to encourage woodlot management to ensure the sustainability of woodfuel in the country.

Keywords: Woodfuel; Fuel value index; Moisture content; Gross calorific value; Density

\section{Background}

Woodfuel is the largest energy source for the world's population in developing countries and the demand is likely to continue [1,2]. The use of woodfuel is both an ancient and modern tradition that is not likely to change in the next decades [3]. Woodfuel is particularly significant to the poor and rural households $[3,4]$. The greatest portion of woodfuel is derived from natural forests, and

\footnotetext{
* Correspondence: sojelel@cns.mak.ac.ug

${ }^{1}$ Department of Biological Science, Makerere University, P.O. Box 7062 Kampala, Uganda

Full list of author information is available at the end of the article
}

the dwindling forest cover has made its availability a matter of critical concern in most developing countries $[5,6]$. The limited availability and high cost of alternative energy resources in Africa continue to make firewood and charcoal the major energy resource [7]. The heavy reliance on woodfuel has escalated the woodfuel demand leading to forest cover decline and inevitable woodfuel shortages in many African countries [8-10].

In Uganda, biomass is the most significant source of energy with a wide range of applications from domestic use such as heating, cooking, and lighting to small-scale

\section{实}


industrial use in bakeries, tea processing, tobacco curing, lime and brick making, fish smoking, jaggeries, and distilleries $[8,9,11]$. It currently accounts for more than $97 \%$ the country's energy supplies $[8,12]$. The daily per capita consumption rate is estimated to be $4 \mathrm{~kg}$ [11]. In the urban areas, people use charcoal more than firewood because the former has lower transport costs per unit energy and higher energy content per ton [13]. However, it is produced inefficiently thus contributing to the scarcity of bioenergy resources.

The relentless demand for biomass energy in Uganda has been attributed to the increasing population, growing industrial sector, as well as increased rate of urbanization [14]. This shows that socioeconomic factors are largely responsible for the dependence on biomass energy resources which are available at low (or even zero) cost while commercial fuels such as liquefied petroleum gas, kerosene, and diesel are often beyond the acquisitive power of most poor people [15]. The socioeconomic characteristics of local communities in Uganda such as age, gender, wealth, education, heterogeneity of the population, household size, land holding, and distance from the forest are believed to greatly influence the level of dependence on firewood [16].

The contribution of natural forests and woodlands to biomass energy supplies in Uganda has been recognized $[9,17]$. However, assessment of woodfuel FVIs from basic properties remains inadequately addressed. This information is important in aiding the identification of high fuel potential woodfuel species to enhance existing woodfuel stocks so that the low-cost energy source is maintained [10]. There is evidence that the improvement of existing stocks is cheaper than establishment of new plantations or woodlots [18]. Indeed, the management of landscapes with the aim of producing woodfuel or maintaining existing stocks requires that woodfuel species with qualities acceptable to rural communities are identified [19]. Besides providing woodfuel, the management of indigenous woodlands is believed to be more ecologically sound and offers better chances for the conservation of biodiversity [9]. It is with this background that this study sought to answer the questions: (i) Which woodfuel species are commonly used by the communities in Masindi and Nebbi districts? (ii) What are their FVIs computed from basic properties (gross calorific value (GCV), density (D), and moisture content (MC))?. This information is vital in prioritizing high fuelpotential tree species for utilization, management, and improvement to ensure a steady supply of woodfuel. This study therefore fits well into the ongoing Government and Civil Society campaigns to maintain woodlots so as to ensure a balance between supply and demand of woodfuel in the country.

\section{Methods}

\section{Study area}

This study was conducted in Masindi and Nebbi districts of Uganda. Nebbi district is located in the north western region of Uganda between $2^{\circ} 20^{\prime}$ and $2^{\circ} 40^{\prime} \mathrm{N}$ and $31^{\circ} 0^{\prime} 0$ and $31^{\circ} 20^{\prime} \mathrm{E}$. It lies at an altitude of 945 to $1,219 \mathrm{~m}$ above sea level. It is bordered by the Democratic Republic of Congo in the East. Meanwhile, Masindi district is located in western Uganda and lies between $1^{\circ} 22^{\prime}$ and $2^{\circ} 20^{\prime} \mathrm{N}$ and $31^{\circ} 22^{\prime}$ and $32^{\circ} 23^{\prime} \mathrm{E}$ and altitude in the range of 621 to $1,158 \mathrm{~m}$ above sea level. These two districts were selected based on their current extensive savannah biomass stocks that supply the major neighboring urban areas.

\section{Selection of informants}

A multistage sampling approach was used to select the informants. In this technique, two sub-counties from Masindi and Nebbi districts (Pakanyi and Nebbi, respectively) were randomly selected; one parish was selected randomly from each sub-county, and four villages were chosen from each parish. A systematic random sampling technique was used to select 10 respondents in each village for the interview totaling to 80 . A semistructured questionnaire was administered to women and girls as the key informants in order to elicit responses on trees used for woodfuel purposes. The free listing technique was applied whereby the respondents were asked to mention any tree that comes to their mind until they could not mention any more species. From the responses, the FI was calculated for each species according to [20], and the ten species with the highest FI (Table 1) were chosen for basic property analysis.

\section{Wood sample collection and preparation}

Wood samples measuring $30 \mathrm{~cm}$ in length and $2.5-\mathrm{cm}$ diameter were collected for each of the ten woodfuel species shown in Table 1 . These samples were prepared according to [15] whereby each was sub-divided into triplicates of length $10 \mathrm{~cm}$, marked and weighed immediately in the field, and brought for analysis in the laboratory. The MC, D, and GCV were determined as described in the subsequent sections.

\section{Moisture content (MC)}

The triplicate samples were dried in an electric oven at $100^{\circ} \mathrm{C}$ until they attained a constant weight. The MC was then determined on dry weight basis according to Equation 1 [21]:

$$
\mathrm{MC}=\frac{W w-W o}{W o} \times 100 \%
$$

where $W w=$ wet weight and $W o=$ oven-dry weight. 


\section{Density $(D)$}

This was determined as a ratio between oven-dry weight (g) and volume $\left(\mathrm{cm}^{3}\right)$ using Equation 3. The procedure followed the technique described in [22] whereby wood volume is first determined by immersing the samples in water for 5 days $(120 \mathrm{~h})$ to achieve total saturation, allowed to drain for $5 \mathrm{~min}$, and their diameters measured using a vernier caliper. The volume was calculated using Equation 2:

$$
\text { Volume }=\frac{\pi \times D^{2} \times L}{4}
$$

where $D=$ average diameter and $L=$ length of the sample.

The samples were again dried at $100^{\circ} \mathrm{C}$ until attaining a constant weight. The $D$ was then calculated according to Equation 3:

$$
\text { Density }=\frac{\mathrm{DW}}{\mathrm{SV}}
$$

where DW = dry weight $(\mathrm{g})$ and SV $=$ sample volume $\left(\mathrm{cm}^{3}\right)$

\section{Gross calorific value}

The GCV of the wood samples was determined using a Gallenkamp autobomb calorimeter (SG96/02/536, Gallenkamp and Company Ltd, London, UK). The method is based on combustion in the 'bomb' chamber. When the sample is burned, the resulting heat is measured by the increase in the temperature of water surrounding the bomb. In this study, $1 \mathrm{~g}$ of wood sample was pelleted using a briquette press and weighed in a crucible. The pellet was then connected to the firing wire fitted between the electrodes with the aid of a cotton thread. The circuit was tested and the bomb was filled with oxygen to a pressure of 3,000 $\mathrm{Pa}(30 \mathrm{bar})$. The calorimeter vessel was filled with water (total weight $3 \mathrm{~kg}$ ) at $21^{\circ} \mathrm{C}$ to $23^{\circ} \mathrm{C}$; the prepared bomb was placed inside the calorimeter vessel, and then the calorimeter vessel was placed into the water jacket. The machine was switched on and left for a while (10 to $15 \mathrm{~min}$ ) to warm up. The initial temperature of the water was recorded before firing and after 10 to 15 minutes, the final temperature reached was recorded. Benzoic acid was used as a standard. The GCV was then calculated using Equation 4:

$$
\mathrm{GCV}=[(F T-I T) \times 10.82]-0.086 /(\text { weight of sample })
$$

where $10.82=$ heat capacity of the calorimeter in $\mathrm{kJ} / \mathrm{K}$, $0.086=$ combined energy value of nickel wire and cotton in $\mathrm{kJ} / \mathrm{g}, \mathrm{FT}=$ final temperature, and IT $=$ initial temperature
Fuel value index (FVI)

This was calculated by considering $D$ and GCVs as positive characters and $\mathrm{MC}$ as the negative character using Equation 5 [19]:

$$
\mathrm{FVI}=\frac{\text { Gross calorific value }(\mathrm{KJ} / \mathrm{g}) \text { Density }(\mathrm{g} / \mathrm{cm})}{\text { Moisture content }(\%)}
$$

\section{Data analysis}

SPSS ver. 16.0 was used to analyze the results. The following tests were carried out: (i) one-way ANOVA on the variability of $\mathrm{MC}, \mathrm{D}$, and GCV, (ii) Pearson product correlation coefficient on the relationship between D and GCV and $M C$ and GCV, and (iii) Pearson rank correlation coefficient on the relationship between FVIs and FIs.

\section{Results and discussion}

\section{Preferred woodfuel species}

Table 1 shows the list of ten commonly used woodfuel species with their FIs. The species are distributed among eight genera and seven families. The family Mimosaceae has three species; Combretaceae has two while the rest have one species each. The genus Albizia and Combretum have two species each and the others have one. Combretum collinum $(\mathrm{FI}=100)$ was mentioned by all respondents as a desirable woodfuel species. This is attributed to its availability in the surrounding environment and apparent possession of desirable woodfuel properties which has been reported elsewhere $[10,13,23,24]$. Tamarindus indica was least mentioned as woodfuel because the benefits from its fruits are seen to outweigh those resulting from woodfuel use.

\section{Woodfuel basic properties and FVls Moisture content}

There was a significant variation in the $\mathrm{MC}$ among the species at $p<0.05$ level $\left(F_{(} d f_{=9)}=92.927, p=0.0001\right)$, and the effect size calculated using eta squared was 0.976 . The MC ranged from $36.18 \%$ in A. grandibracteata to $69.41 \%$

Table 1 Ten commonly used woodfuel species

\begin{tabular}{llll}
\hline Species & Local name & Family & FI (\%) \\
\hline Combretum collinum Fres & Mukora & Combretaceae & 100 \\
Acacia hockii De Wild & Oryang & Mimosaceae & 90 \\
Vitellaria paradoxa C.F. Gaertn & Yao & Sapotaceae & 70 \\
Ficus natalensis Hochst & Bongu & Moraceae & 60 \\
Albizia grandibracteata Taub & Murongo & Mimosaceae & 55 \\
Vernonia amaygdalina Delile & Kibirizi & Compositae & 50 \\
Albizia coriaria Welw. ex Oliver & Musisa & Mimosaceae & 45 \\
Grewia mollis L. & Opobu & Tiliaceae & 45 \\
Combretum molle R. Br. ex G. Don & Murama & Combretaceae & 35 \\
Tamarindus indica Linnaeus & Cwa & Caesalpiniaceae & 25 \\
\hline
\end{tabular}


in Ficus natalensis (Table 2). Assessment of the Pearson product moment correlation coefficient between $\mathrm{MC}$ and GCV showed a negative correlation $(r=-0.518, n=30$, $p=0.003$ ) with $26.83 \%$ coefficient of determination. This confers with the widely held acknowledgement that MC adversely affects the calorific value of the wood $[10,25]$. However, a one-to-one examination showed that $F$. natalensis deviates from this widely held inference conferring with the trend that [6] also reported. Water in green tissues exists primarily in the form of free water filling the capillaries and as water of constitution (e.g., water absorbed in lignocellulose) [6]. The variation in the number and size of wood capillaries and water of constitution is a key determinant of MC variation across species [26]. This therefore implies that species with high $\mathrm{MC}$ have a large number and size of wood capillaries and consequently water of constitution than those with low MC.

\section{Density}

There was a significant variation at $p<0.05$ level $\left(F_{(d f=9)}=\right.$ $11.528, p=0.0001$ ) in the $D$ of woodfuel species and the effect size was 0.84 determined using eta squared. The $D$ values ranged from $0.23 \mathrm{~g} / \mathrm{cm}^{3}$ in F. natalensis to $0.64 \mathrm{~g} /$ $\mathrm{cm}^{3}$ in A. grandibracteata (Table 2). A strong positive correlation between $D$ and GVC was obtained using Pearson product moment coefficient $(r=0.895, n=30, p=0.0001)$ with a coefficient of determination of $80 \%$. This trend was also reported by $[27,28]$. The $D$ values obtained in this study are, however, lower than those reported in [9] due to

Table 2 Basic properties and FVls of woodfuel species used in Masindi and Nebbi districts

\begin{tabular}{lllll}
\hline Scientific name & $\begin{array}{l}\text { Moisture } \\
\text { content }(\%)\end{array}$ & $\begin{array}{l}\text { Density } \\
\left(\mathbf{g} / \mathbf{c m}^{\mathbf{3}}\right)\end{array}$ & $\begin{array}{l}\text { Gross calorific } \\
\text { value (KJ/g) }\end{array}$ & $\mathbf{F V I}$ \\
\hline $\begin{array}{l}\text { Combretum collinum } \\
\text { Fres }\end{array}$ & 47.19 & 0.47 & 23.49 & 5.50 \\
$\begin{array}{l}\text { Albizia grandibracteata } \\
\text { Taub }\end{array}$ & 36.18 & 0.65 & 20.95 & 13.09 \\
$\begin{array}{l}\text { Vernonia amaygdalina } \\
\text { Delile }\end{array}$ & 54.04 & 0.52 & 24.79 & 6.06 \\
$\begin{array}{l}\text { Albizia coriaria } \\
\text { Welw. ex Oliver }\end{array}$ & 51.87 & 0.59 & 23.14 & 7.60 \\
$\begin{array}{l}\text { Combretum molle } \\
\text { R. Br. ex G. Don }\end{array}$ & 50.42 & 0.49 & 24.64 & 5.93 \\
$\begin{array}{l}\text { Vitellaria paradoxa } \\
\text { C.F. Gaertn }\end{array}$ & 48.97 & 0.45 & 22.79 & 4.87 \\
$\begin{array}{l}\text { Grewia mollis L. } \\
\begin{array}{l}\text { Tamarindus indica } \\
\text { Linnaeus }\end{array}\end{array}$ & 37.47 & 0.47 & 25.77 & 7.61 \\
$\begin{array}{l}\text { Acacia hockii } \\
\text { De Wild }\end{array}$ & 48.61 & 0.41 & 24.71 & 5.00 \\
$\begin{array}{l}\text { Ficus natalensis } \\
\text { Hochst }\end{array}$ & 69.41 & 0.23 & 29.46 & 1.10 \\
\hline
\end{tabular}

the use of small-dimension samples in this study which are less dense than the whole branches used in the previous study (Table 3). Wood density describes the proportion of a stem that is tissue and cell walls (xylem conduit walls) and space within cell walls (xylem conduit apertures) [29]. Woodfuel species with high D have high fiber tissue per unit volume and thick fiber walls than those with low D [29], more carbon and energy content per unit volume [30], and produce long-lasting embers [19,31]. However, like the findings of [32], this investigation also found that $F$. natalensis with a low $\mathrm{D}$ (Table 2) has a high GCV. Although it was not investigated during study, high GCVs have been attributed to high concentrations of extractives and lignins in wood [31] and is therefore a plausible explanation for this exception.

\section{Gross calorific value}

The variation in GCVs of woodfuel species was insignificant at $p<0.05$ level $\left(F_{(d f=9)}=1.400, p=0.253\right)$ which is also reported by [25]. The values obtained ranged from $20.05 \mathrm{KJ} / \mathrm{g}$ in A. grandibracteata to $29.46 \mathrm{KJ} / \mathrm{g}$ in $F$. natalensis (Table 2). Woodfuel species with high GCVs have high concentrations of extractives and lignins in wood while a predominance of sugar units such as cellulose and hemicellulose leads to lower GCVs [31].

\section{Fuel value index}

The FVIs ranged from 1.10 in F. natalensis to 13.09 in A. grandibracteata (Table 2). There was a positive but insignificant relationship between FVIs and FIs $(r=0.62$, $n=10, p=0.056$ ). This positive relationship between FVIs and FIs indicates that local preference is partly informed by physical (basic) properties of the wood. The values generated here are lower than those obtained by the authors in [9] who considered D and MC only (Table 3). The variation in the geographical location of the studies is also a plausible source of this difference. The FVI is an insightful parameter for screening woodfuel species [10], and it can be concluded that A. grandibracteata with the highest FVI possesses better woodfuel properties. However, authors in [19] assert that rural people are very

Table 3 Comparison between current and [9] results

\begin{tabular}{llllllll}
\hline \multirow{2}{*}{ Species } & \multicolumn{3}{l}{ Current study } & & \multicolumn{3}{l}{ Tabuti et al. [9] } \\
\cline { 2 - 3 } & Density & MC & FVI & & Density & MC & FVI \\
\hline Combretum collinum & 0.47 & 47.19 & 5.5 & & 0.82 & 14.2 & 53.5 \\
Ficus natalensis & 0.23 & 69.41 & 1.10 & 0.49 & 16.5 & 29.9 \\
Combretum molle & 0.49 & 50.42 & 5.93 & 0.77 & 14.1 & 46.5 \\
Vernonia amaygdalina & 0.52 & 54.04 & 6.06 & 0.58 & 16.0 & 34.9 \\
Albizia coriaria & 0.59 & 51.87 & 7.60 & 0.56 & 16.0 & 35.0 \\
Grewia mollis & 0.47 & 37.47 & 7.61 & 0.61 & 14.6 & 41.8 \\
Acacia hockii & 0.38 & 48.61 & 3.63 & 0.69 & 14.1 & 48.9 \\
\hline
\end{tabular}


discerning about woodfuel requirements and therefore socially acceptable features also need to be considered to generate woodfuel species checklist in a given locality.

\section{Conclusions}

The woodfuel species used in Masindi and Nebbi districts show significant variations in $\mathrm{MC}$ and $\mathrm{D}$. These two variables are therefore more important in assessing woodfuel species. The results further emphasize that a single basic property is not sufficient to justify selection of the most suitable woodfuel species thereby conferring with authors in [10]. On the proposition of the FVIs, A. grandibracteata is a more suitable woodfuel species than $F$. natalensis. This study therefore lays an important premise for selection of high fuel potential woodfuel species for possible inclusion into reforestation, afforestation, and agroforestry initiatives currently encouraged by the Government and Civil Society Organizations to address woodfuel shortage in Uganda generally. However, before such species prioritization is done, it is recommended that socially defined features that shape local peoples' perception of acceptable woodfuel species need to be considered $[6,19]$ which was not undertaken in this study. This will lead to the generation of woodfuel species checklist that is socially acceptable and with high fuel potential in a given area.

\section{Competing interests}

The authors declare that they have no competing interests.

\section{Authors' contributions}

SO was responsible for data collection, laboratory experiments, analysis, and drafting of the manuscript. TO and SM were in charge of the study design, reviewing the manuscript draft, and overseeing the research. All the authors have therefore contributed substantially to this manuscript. All authors have read and approved the final manuscript.

\section{Authors' information \\ TO is a professor in the Department of Physics, Makerere University. He is also the chairman, Uganda National Energy Development Organization (UNEDO); member of African Energy Policy Research Network (AFREPREN); group leader, Solar Energy Research Group, Physics Department, Makerere University; Member of the International Energy Foundation (IEA) and a member of the Scientific and Technical Advisory Panel (STAP) of the Global Environment Facility (GEF). SM (PhD) is a lecturer in the Department of Biological Sciences of Makerere University. SO is a teaching assistant in the Department of Biological Sciences, Makerere University and also a post graduate student in the same Department.}

\section{Acknowledgements}

The authors acknowledge the support by Makerere University Staff Development Program and DAAD In-Country Scholarship program for Uganda for SO. We thank Robert Nuwamanya, the laboratory technician at College of Agricultural and Environmental Sciences, Makerere University for his technical guidance in GCV determination. We also thank the communities of Masindi and Nebbi for willingly participating in our interviews.

\section{Author details}

'Department of Biological Science, Makerere University, P.O. Box 7062, Kampala, Uganda. ${ }^{2}$ Department of Physics, Makerere University, P.O. Box 7062, Kampala, Uganda.

Received: 18 October 2014 Accepted: 10 April 2015

Published online: 28 April 2015

\section{References}

1. Scurlock JM, Hall DO (1990) The contribution of biomass to global energy use. Biomass 21:75-81

2. Deka D, Saika P, Konwer D (2007) Ranking of woodfuel species by fuel value index. Energy Sources Part A 29:1499-506

3. Matthews E (2000) Undying flame: the continuing demand for wood as fuel. Extract from pilot analysis of global ecosystems: forest ecosystems. Earth trends 2001 World Resources Institute

4. Hall DO (1994) Introduction, summary and conclusions. In: Hall DO, Mao YS (eds) Biomass energy and coal in Africa. Zed Books and AFREPREN, London, pp 1-16

5. Delali BKD, Witkowski ETF, Shackleton MC (2004) The fuelwood crisis in southern Africa-relating fuelwood use to livelihoods in a rural village. Geo J 60:123-33

6. Shanavas A, Kumar BM (2003) Woodfuel characteristics of tree species in home gardens of Kerala, India. Agroforestry Syst 58:11-24

7. Pak SL (2005) Climate change and Africa. Cambridge University Press, Cambridge, p 412

8. NEMA (2008) State of the environment report for Uganda. National Environment Management Authority, Kampala, Uganda

9. Tabuti JRS, Dhillion SS, Lye KA (2003) Firewood use in Bulamogi County, Uganda: species selection, harvesting and consumption patterns. Biomass Bioenergy 25(6):581-96

10. Abbot PG, Lowore JD (1999) Characteristics and management potential of some indigenous firewood species in Malawi. For Ecol Manage 11:111-21

11. Forest department (2003) National biomass study technical report of 1996-2002. Ministry of Water and Environment. Kampala, Uganda

12. MEMD (2006) Renewable energy policy for Uganda. Ministry of Energy and Mineral Development. Kampala, Uganda

13. Agea JG, Kirangwa D, Waiswa D, Okia CA (2010) Household firewood consumption and its dynamics in Kalisizo sub-county, central Uganda. Ethnobotanical Leaflets 14:841-55

14. UBOS (2010) Statistical abstract. Uganda Bureau of Statistics (UBOS), Kampala

15. Bhatt BP, Tomar JMS (2002) Firewood properties of some Indian mountain tree and shrub species. Biomass Bioenergy 23:257-60

16. Turiho-habwe GP (1995) A socio-economic analysis of communal resource use: the case of non-gazetted forests of western Uganda. Makerere University, Kampala, MSc Thesis, 108 pp

17. Katende AB, Birnie A, Tengnas B (1995) Useful trees and shrubs for Uganda: identification, propagation and management for agricultural and pastoral communities. Regional Soil Conservation Unit (RSCU), Nairobi, Kenya

18. Harrison P (1987) The greening of Africa: breaking through in the battle for land and food. Paladin, London, $371 \mathrm{pp}$

19. Abbot PG, Lowore J, Khofi C, Werren M (1997) Defining firewood quality: a comparison of quantitative and rapid appraisal techniques to evaluate firewood species from a southern African savanna. Biomass Bioenergy 12:429-37

20. Tabuti JRS (2007) The status of non-cultivated food plants in Balumogi County, Uganda. African J Ecol 45(1):99-101

21. Valter F, Antonini E, Bergoni LZ (2008) Wood fuels handbook: production, quality requirements and trading. Italian Agroforestry Energy Association, p 19. Agripolis, Italy.

22. Alves Ramos M, de Medeiros PM, de Almeida ALS, Feliciano ALP, de Albuquerque UP (2008) Can wood quality justify local preferences for firewood in an area of Caatinga (dryland) vegetation? Biomass Bioenergy 32:503-9

23. Tietema T, Ditlhogo M, Tibone C, Mathalaza N (1991) Characteristics of eight firewood species of Botswana. Biomass Bioenergy 1:41-56

24. Shackleton CM, Griffin NJ, Banks DI, Mavrandons JM, Shackleton SE (1994) Community structure and species composition along a distribution gradient in a communally managed South African savanna. Vegetation 115:157-67

25. Kataki R, Konwer D (2002) Woodfuel characteristics of indigenous tree species of North East India. Biomass Bioenergy 22:433-7

26. Skaar C (1988) Wood-water relations. Springer, Berlin, pp 20-33

27. Bhatt BP, Todaria NP (1992) Woodfuel characteristics of some mountain species. Forest Ecol Manag 47:363-6

28. Jain RK, Singh B (1999) Woodfuel characteristics of selected indigenous tree species from central India. Bioresour Technol 68(3):305-8

29. Hakkila P (1984) Forest chips as fuel for heating plants in Finland Summary: forest seasoning of wood intended for fuel chips. Communications Insituti Fenniae 54 (4): 82, Finland. 
30. Shafizadeh F (1981) Basic principles of direct combustion. In: Sofer SS, Zabrosky OR (eds) Biomass conversion process for energy and fuels. Plenum, New York, pp 103-12

31. Kataki R, Konwer D (2001) Woodfuel characteristics of some woody species of North East India. Biomass Bioenergy 20:17-23

32. Singh B, Khanduja SD, Srivastava GS (1984) Qualitative analysis of some firewood shrubs. Biomass 5:317-20

Submit your manuscript to a SpringerOpen ${ }^{\circ}$ journal and benefit from:

- Convenient online submission

- Rigorous peer review

- Immediate publication on acceptance

- Open access: articles freely available online

- High visibility within the field

- Retaining the copyright to your article

Submit your next manuscript at springeropen.com 